\title{
SMALL WARS AND PEOPLE'S WARS: A CLAUSEWITZIAN PERPECTIVE ON THE SOUTH AFRICAN WAR, 1899-1902
}

\author{
Pieter Labuschagne \\ Department of Political Sciences \\ UNISA
}

\begin{abstract}
The theorist and strategist Carl von Clausewitz developed core theoretical concepts on war, including that war is merely an extension of politics by different means, and that the integration of morality and rationality functions as a driving force in a people's war. Clausewitz envisaged the idea of war in its absolute perfection ('beautiful wars') as a regulative ideal, which formed part of his framework on small wars and people's wars. The aim of this article is to demonstrate how Clausewitz's theories on small wars, and their transformation into people's wars, are still valuable when analysing and contextualising historical events and battles. The value of Clausewitz's theories on small wars and people's wars is demonstrated by applying them to the general characteristics of the South African War of 1899-1902. The way Clausewitz differentiates between the underpinning reasons for war, and between 'limited' and 'absolute' war, is specifically relevant for understanding the different tactics which commanders adopted in the field of battle. The theoretical distinction that Clausewitz makes between the objectives of two opposing forces could clarify why the British Empire and the two Boer Republics went to war. The same distinction might explain the motives and the impetus that gave rise to divergent views, and how the subsequent conflict developed into a full-scale war.
\end{abstract}

\section{Introduction}

General Carl von Clausewitz (1780-1831), an avid analyst of small wars and people's wars, is generally acknowledged as one the greatest writers on the theory of war. This is an astonishing achievement, especially as he wrote only one major work during his career, On War [Vom Kriege]. This publication represents the culmination of his theories, which he himself referred to as "a shapeless mass of ideas". ${ }^{58}$ Yet, despite Clausewitz's modesty, he had an undeniably dominant global impact on theories about war for an extended period. The American strategist, Barnard Brodie, made the bold statement that Clausewitz's "work is not simply the greatest, but the only book about war". ${ }^{59}$ In the field of academics, many prominent scholars and experts on international relations and strategic studies, including Raymond Aron, have attached significant prominence to Clausewitz's theories in their textbooks. ${ }^{60}$ 
As Scheipers indicates, it was inevitable that in recent reconfigurations, the contextualisation of Clausewitz's theories on war would distance him from the twentyfirst-century theoretical-strategic context. ${ }^{61}$ Herberg-Rothe refers to studies since the 1990 s, where influential writers on the theory of war have argued that Clausewitz's theories are no longer applicable, not only in relation to contemporary conflicts, but also in general. Van Creveld (1991) is even more forthright in describing Clausewitz's theories as harmful, while Keegan (1993) goes so far as to describe Clausewitz's ideas as destructive. ${ }^{62}$ The common denominator in criticisms of Clausewitz's theoretical propositions is their focus on conventional wars between two 'regular' armies. The authors point out that in the modern era, the character and fabric of war are multifaceted and involve a wider range of role players, including non-state actors. than. ${ }^{63}$

It is conceivable that Clausewitz's contribution to the theoretic-strategic aspects of warfare will lose some status; yet, despite his theories falling out of favour, his theoretical insights remain enduring and remarkable, and should be understood and appreciated in the appropriate historical context. His ideas are still relevant, even though military conditions and warfare have modernised and transformed beyond all recognition. Contemporary developments do not warrant the proposal that his ideas be dismissed out of hand. If Clausewitz's writings were to become redundant because of global changes and modernisation, then Aristotle's theories on the state should similarly be dismissed for having been based on a comparative study of ancient citystates situated around the Mediterranean in about 300 BC. $^{64}$

Daase labels the criticisms against Clausewitz "intellectual ignorance." ${ }^{65} \mathrm{He}$ points out that even authors who defend Clausewitz, attack his critics rather than pointing out his analytical strengths. Daase explains that the new forms of warfare underscore Clausewitz's contemporary relevance, and that his ideas on 'small wars' allow a sophisticated approach to political violence. ${ }^{66}$ Within this scope, contrary to some contemporary views, Clausewitz's theoretical propositions still have relevance and value, specifically in helping to differentiate between 'small wars and 'people's wars' It is thus the purpose of this article to demonstrate how his theories on small wars, and their transformation into people's wars, make a valuable contribution to any analysis that aims to contextualise historical events and small wars.

\section{Aim of the article}

It was pointed out in the introduction that Clausewitz's thoughts on small wars and people's wars remain contemporary and relevant as analytical tools. The aim of this article is to demonstrate the value of Clausewitz's theories by applying their general characteristics as a theoretical construct to explain the dynamics and inherent facets of the South African War of 1899-1902. The South African War displayed multiple dimensions for analysis because it was conducted between two unequal opponents - the mighty British Empire and two smallish Boer Republics (the South African Republic [Transvaal] and the Orange Free State Republic) and between a modern professional army and a militia or a 'people's army'. For the Boer Republics, it was a war on their own territory, for their freedom and independence - which Clausewitz deemed the most beautiful type of war. 
The value of Clausewitz's views and theories on small wars and people's wars is that these theories and views offer additional, intriguing strategic and military insight into the defining aspects of the South African War. His eighteenth-century theoretical conceptualisations find an echo in the salient features of that war more than a century later. The distinction Clausewitz draws between the underpinning reasons for war and the differences between 'limited' and 'absolute' war necessitates a focus on the different tactics adopted by the respective commanders. Clausewitz's eighteenthcentury theoretical disposition and the distinction he made in terms of a war between a professional army and a 'people's army' is invaluable for the analysis undertaken in the study on which this article reports.

According to Scholtz, Clausewitz's reference to a Landwehr is a concept that could be equated with the concept of a civil force or a 'people's army. The civil force is an extraordinary voluntarily force consisting of the whole of society, with all their physical and inner strength, their assets and goodwill - these assets form the basis of the Landwehr. ${ }^{67}$

The theoretical distinction between the objectives of the two opposing forces makes it possible to explain why the British Empire and the two Boer Republics went to war in the first place. That same distinction explains the impetus that led to divergent views forming, and the way the subsequent fighting developed into a fullscale conflict.

\section{Structure of the article}

The stated aim of the article is to expound how Clausewitz's theories could be applied to facets of the South African War. The aim is to explain how a people's army fought a people's war, for their independence and freedom, which sprang from the concept of aestheticism as a combination of morality/passion and reason.

The next subsection will outline the distinction between limited and absolute war, with reference to the difference between the strategic approaches of the British Empire and the Boer Republics. The differences will be explained with specific reference to the aim of the British Empire to extend its imperial policy and, in direct opposition, the Boer Republics' aspirations for complete emancipation from British domination.

The next subsection provides an outline of the inner individual motivation of the average Boer in the militia, having morality as a defining trait. The resolve of the Boer militia was strengthened by a unique blend of morality and rationality, coupled with strong religious convictions. It is also explained that subsequent events during the war progressively undermined the rational and later moral beliefs of the Boers to continue fighting. In the conclusion of this article, final comments are offered to explain that the events, such as the Boer defeat at Paardenberg and the surrender of 4000 men, served to demoralised the Boers, and started the process of abandonment of a concerted resistance against the professional British army. 


\section{Theoretical underpinning}

The level of intensity shown by those individuals who fought a people's war to secure their own independence and freedom, sprang from the concept of aestheticism. The aesthetic disposition shows efficacious interaction between morale/passion and reason as a central tenet, and in this instance, it provided the driving force energising the men on the battlefield. Those who fought on this basis were imbued with the ideals and moral disposition to defend their own soil vigorously ${ }^{68}$ In Clausewitz's theoretical assumption, the 'most beautiful of wars' thus relates to the intrinsic presence of moral and aesthetic elements that are inherent in those willing to defend their motherland against invading aggressors. Clausewitz emphasises that small wars transform from partisan wars into people's wars if they are underpinned and supported by a combination of reason (rationality) and morality, which legitimises and propels citizens' resistance.

Within a broader context, an illustrative comparison can be drawn between the political and military-strategic positions of the two Boer Republics at the beginning of the nineteenth century when their independence and very survival were at stake on the one hand, and the situation in Prussia a century earlier on the other. Clausewitz's views on Prussia's political and strategic challenges included his notion of a people's war as involving citizens defending their country/nation against an aggressor. ${ }^{69}$ In the two former Boer Republics, the same salient features of a people's war were present when Afrikaners fought to preserve their independence and maintain their sovereignty. In terms of the Clausewitzian aesthetic context, the forces of the two republics were imbued with a sense or an awareness of the legitimacy of their course of action, based not only on rational grounds, but also on an interrelationship with morality.

During the first few months of the war, the two Boer Republics were able to draw on strong feelings of unity and solidarity in defence of their sovereignty. Their defence was underpinned by a moral justification of their cause, based on firm notions of morality and rationality. The Boer militia were convinced they were fighting 'for the right reasons' and 'rationally believed' in their own military prowess. It was this combination of morality and rationality that motivated and united the Boer militia and, for them, legitimised their struggle. These strong convictions resulted in remarkable victories during the last few months of 1899 over the British forces at Colenso, Stormberg and Magersfontein. However, the defeat and capitulation of General AP Cronjé at Paardenberg on 27 February1900 (Majuba Day) was a watershed and turning point in the war. The demoralising effect of the surrender of almost 4000 men was a devastating blow to the Boer fighters. In the weeks following this loss, the interrelationship between rationality and morality that had underpinned and legitimised the Boers' war up to that point was shattered by the surrender at Paardenberg and the strategic blunder made by the two presidents during the aftermath of the battle.

Paardenberg represented another watershed juncture in the history of the Boer militia. It manifested as a split between those who wished to continue and those 
demanding a ceasefire or a halt to the fighting. The division amongst the Boer militia pitted the diehards (bittereinders) (who believed that the war should continue on rational and moral grounds) against the 'joiners' (Boers who, as the name suggests, joined the British forces in various capacities), and the 'hands-uppers' (those raising their hands in surrender) who harboured opposing views. This bitter split resembled the start of a civil war, in that a number of Boers were killed by the actions of the 'joiners' - their erstwhile compatriots - and for decades after the war, this betrayal reverberated through the districts. ${ }^{70}$ The division that occurred eroded the moral fabric of a people's war and fragmented the solidarity of the two republics, rendering them unable to resist the invaders as the war progressed. As Warwick indicates, there is little doubt that in legal terms, the 'joiners' were regarded as wartime traitors. ${ }^{71}$

\section{Distinction between the Clausewitzian 'limited' and 'absolute' war and perspectives on the South African War}

In a letter to the German philosopher Johann Fichte in 1869, Clausewitz outlines his perspectives on the broad spectrum of war, comparing the notion of the "most unfortunate of wars' (seen from the perspective of the occupying powers) with the 'most beautiful of wars' (in which people fight on their own territory for their freedom and independence). ${ }^{72}$

From this proposition, Clausewitz then deduces the tendency of fighting to escalate to absolute war - a process which he terms the 'dialectics of the contest' ${ }^{\text {' }} 3$ He postulates that it is unavoidable that when one side attempts to dictate the law to another with the intention to enforce its will, there will be a reciprocal action, which will then logically lead to an escalation and ultimately an extreme form of warfare, i.e. absolute war. $^{74}$

In terms of Clausewitz's theoretical thinking, the motivating factors in each form of war differ fundamentally. The difference between the two strategic approaches is that the underpinning motive of the occupying force is to fight to eliminate the opponent's political independence, while the defending force fights to preserve its freedom and independence. In the event of the defender being unable to repel the occupier, the former is compelled to fight to obtain favourable terms to secure peace. ${ }^{75}$ In addition to studying the differences between two opposing commanders' strategic approaches, Clausewitz emphasises the importance of understanding their ultimate aims as well as the strategies they used. ${ }^{76}$

Daase refers to Clausewitz's definition of small wars as the application of organised and unorganised violence by non-state actors against military forces to harass and exhaust the enemy's army in order to change its policy. ${ }^{77}$

An important aspect is Clausewitz's differentiation as both these wars ('small wars and people' war) being the opposite of absolute war. To this end, Clausewitz refers to the seventeenth-century tradition of German philosophical and aesthetic discourse (see earlier) to emphasise the fundamental importance of the integration or 
interrelationship between passion and reason as an underpinning factor in small wars and people's wars. At that time, Prussia's survival was at stake, and the importance of integrating logic and fervour was paramount, if the Prussians wanted to repel the danger of the invading German forces. ${ }^{78}$

Clausewitz makes a clear distinction between absolute and limited war: the former aims to eliminate the enemy's political independence, while the latter hopes to obtain favourable terms of peace. To this end, Clausewitz urges a commander to know whether he is fighting "the kind of war that is completely governed and saturated by the urge for a decision or one that approximated rather to "a war of observation" 79

The compelling reasons why the British Empire and the two Boer Republics went to war in 1899 differ on a fundamental level from the aforementioned Clausewitzian classification. The British Empire engaged in war because it was the next logical step in its imperial policy, following the Anglo-Transvaal War of 1880-1881. That war had resulted in humiliation for the British and the annihilation of General Colley's forces at Amajuba. The British government's imperialistic perspective ideologically dominated and defined its outlook on international relations during the nineteenth century. In direct contrast, the Transvaal Republic had clearly stated its ambitions for complete emancipation from British domination, which was given further impetus by the discovery of gold on the Witwatersrand. The advantages of an influx of money to the Transvaal Treasury reinforced the republic's autonomy, and this was disconcerting for the expansive hopes of the British imperialists. ${ }^{80}$

The republic's impetus to strive for complete emancipation from British rule was thus incompatible with the imperialists' policy and ambitions to establish supremacy over most of Southern Africa. The Transvaal's separatist policies and dreams were disquieting to the imperial leaders, who envisaged the possible future impact thereof on the British colonies of Natal and the Cape. This predictably led to a widening of the rift. The Boer leaders, Presidents Paul Kruger and MT Steyn, realised after the collapse of the Bloemfontein Conference on 5 June 1899 that no solution regarding their differences with the British government, other than capitulation, was possible. The failure of these talks made the two Boer presidents realise that their independence was a stake, and that only war would preserve their independence from Britain's imperialistic policies. ${ }^{81}$ It was during the failed Bloemfontein Conference that Kruger blurted out to the British High Commissioner, "it is our country that you want". ${ }^{82}$

The Boer leadership realised they would have to resist the British Empire's imperialistic agenda through armed struggle; yet, in spite of their awareness of the threat posed by the British, the Transvaal Republic's preparation for the upcoming war was restricted and rather limited in scope. Jan Smuts, Attorney General of the Transvaal Republic, was tasked with drafting a memorandum as a basis for preparing for the looming war. To this end, he provided the government with a blueprint for political, economic and military action. Smuts adopted a propagandistic/diplomatic approach to the war, being of the opinion that many subjects of the British Empire were antagonistic towards their rulers. He believed their loyalty was divided, and that 
this would weaken the efforts by the empire to subdue the republics. Smuts was also of the opinion that the empire and the imperial structures were overextended and would be tested if compelled to wage a drawn-out war in Southern Africa. ${ }^{83}$

Smuts was, in the light of the two variables, propagandistic and diplomatic, in favour of a propagandistic approach intended to stir up the populace in the two British colonies, Natal and the Cape, to oppose the war. He also believed that the Afrikaners in the two republics and in the two colonies could fight a 'people's war'. To this end, he suggested in his memorandum that a firm economic policy be adopted, with increased output in the agricultural and manufacturing sectors, to supply materials to boost the war effort. These measures needed to be supported by increased gold production, which would boost the Treasury and enable it to finance the war. In terms of strategy, he believed the Boer forces should go on the offensive from the outset against the British forces assembled across the border in the colonies of Natal and the Cape. Smuts believed the Boer forces should immediately grab the initiative and gain the upper hand, particularly in Natal, and that the railway line between the Cape Colony and Rhodesia should be sabotaged to prevent British aid arriving from that quarter. $^{84}$

In a Clausewitzian context, the available manpower in the two Boer Republics constituted a people's army (militia) - the ideal force for a people fighting on its own territory for its freedom and independence ${ }^{85}$ The Boer forces formed the purest kind of nation-in-arms, with only a very small permanent attachment, mostly made up of police and artillery: about 600 state artillery members and 1400 state police (ZuidAfrikaansche Republiek Politie [ZARP]) in the Transvaal and fewer than 400 artillery troops in the Orange Free State. All other military sources were drawn from the civilian population in the two republics as a militia force. Each district was subdivided under two to four field cornets who then elected a commander (commandant) when war was declared. The selection of a commander rested mainly on his popularity and family connections, rather than his military ability. ${ }^{86}$

The defects of the Boer military system were also one of the strong points of its system, because individualism, personal initiative and the paramountcy of the individual and small groups had always been the strength of the Boer militia. The individual Boer was someone capable of thinking and reacting for himself, able to respond on an individual basis to dangerous situations. However, this characteristic disposition was admittedly better suited to scattered forces fighting on their own terms than within a larger unit. The shortcoming of individuals thinking independently was that they tended to act unilaterally and intuitively - the overall strategy of the larger force therefore suffered accordingly. ${ }^{87}$

The initial restricted mobilisation of the Boer militia demonstrated that their leadership approached the conflict as a limited rather than an absolute or an absolute war. On the eve of the war, the Boer forces deployed a force of around 35000 men, which represented only 65 per cent of the joint capacity of the two republics. This raises the question why the commanders did not employ the full might of the men 
available from the outset, to provide a 'killer blow' to their foe. The Boer leaders' initial strategy was to cut off any reinforcements from the empire by attacking the existing forces in Northern Natal, and ensuring that they would not receive help from the mainland. It would, however, have been strategically advantageous to employ more men from the start and achieve the objective more swiftly by adopting stronger offensive strategies. That hesitation - especially on the part of older generals such as PJ Joubert and AP Cronjé - led to periods of inactivity, and the Boers' initial successes petered out in drawn-out sieges. The opening campaign, which had resulted in spectacular victories during Black Week in early December 1899, was not followed up. During the subsequent weeks, the Boer initiatives stagnated as they assumed defensive positions or remained immobile, and were unable to overwhelm the fortified positions at Kimberley, Mafeking and Ladysmith. ${ }^{88}$ Attempts at the largescale recruitment of Boer sympathisers and a subsequent uprising in the Cape Colony largely failed. Initial Boer successes at maintaining defensive positions, such as on 11 December 1899 at Magersfontein, strengthened the perception that it was the ideal strategy to follow. Eventually, however, it was the immobility of the Boer forces which led to their defeat at Paardenberg - a pivotal battle, which saw the tide turning against the two Boer Republics. ${ }^{89}$

The two opposing sides' dissimilar reasons for waging war became more apparent immediately after Cronjé's forces surrendered. In the Clausewitzian idiom, the difference lay in their ultimate objectives: either to eliminate their opponent's political independence (absolute war) or fighting to maintain their own independence (people's war).$^{90}$ After the setback of Cronjé's surrender, the Boer leaders, Presidents Kruger and Steyn, opted to adopt a two-pronged strategy. They decided they would follow the route of international diplomacy, while attempting to re-energise the commandos. The presidents cabled the British Prime Minister, Lord Salisbury, on 5 March 1900, expressing profound sentiments about the war by unambiguously stating their desire for peace, but only on the basis that they retained their independence. Kruger and Steyn stated in their cable that if the intention of the British government was to destroy the sovereignty of the two republics, the Boers would fight to the bitter end. ${ }^{11}$ In his response to the communication, Salisbury once again made clear the intention of the British government by stating that it was not prepared to accede to the demands of either the South African Republic or those of the Orange Free State. ${ }^{92}$

The Boer leaders were clearly disappointed by the response, although they were politically naïve in assuming that the British government would cede to their request directly, now that the tide of the war had turned in its favour after being humiliated during the opening campaigns. The two presidents, in their communication to the British government, also made overtures through diplomatic channels to Germany, the United States of America, the Austrian Empire, Belgium, France, the Netherlands, Italy, Russia and Switzerland to intervene in the war, with a view to establishing peace. They further sent abroad a diplomatic team, consisting of A Fisher, AD Wolmarans and CJ Wessels, to negotiate directly with the major powers to intervene ${ }^{93}$ or assist in the war effort. ${ }^{94}$ 


\section{Clausewitz on individuality and the reasons for fighting the war: a theoretical and philosophical perspective}

In the preceding subsection, the individuality of the average Boer serving in the militia was singled out as a strength within a more restricted form of war. The Boer militia were motivated in their struggles and in fighting their opponents by their unique strengths and their strong inner belief in the righteousness of their struggle. The history of all citizens' wars (i.e. people's wars) shows that a nation achieves infinitely more by vitalising individual energies than by relying on artificial forms of motivation. In this context, the contributing factor is the moral and intellectual strength of the individual. In the case of Prussia, it was individuals' inner strength that served to ignite the country's resistance and success in a people's war. In his writings, Clausewitz emphasises to the Prussian officers that the strength of individuals in small wars is the deciding and determining factor when victory is at stake. Reinforcing this is the tactical capacity of the individual in a people's war: in aesthetic terms, having morality as a defining trait (an aspect which is absent from most professional armies).

Although Clausewitz abhorred war and the cruelty of it, he continued to refer to "beauty of war" 95 , driven by his strong belief in the value of aesthetics. He formed this perspective as a result of the influence of Immanuel Kant and Friedrich Schiller. Kant emphasised that knowledge based on experience involves three faculties: sensibility, imagination and understanding. The notion of understanding allows an individual to compartmentalise experiences according to rational concepts. According to Kant, the characteristic feature of the aesthetic experience is therefore that it initiates a process in which sensibility (morality) and understanding enter into a free play of harmonious activity in which neither gains the upper hand, but one furthers the other and vice versa. This clearly indicates that rationality (as understanding) plays a central role in the aesthetic experience of morality, without it (rationality being the ultimate arbiter. ${ }^{96}$

Kant's idea of beauty comprises a number of features. Beauty is a concrete experience, which is sensual without being linked to immediate interests (such as sexual desires). It is also social. The experience of beauty has a vitalising effect on all human faculties in so far as people enter into a free play of harmonious activity. More important to Kant is the fact that the beatifutiful was the symbol of the morally good and that the concept of morality inhabits the realm of rationality. ${ }^{97}$ However, Kant emphasises that morality cannot be experienced through the senses, because moral notions (such as freedom) cannot be derived in a rational way. The reason is that moral notions lack empirical demonstrability. In this sense, the experience of beauty is the counterpart of the concept of morality. The first is empirical without arriving at a rational concept; the second is conceptual, but devoid of empirical content. It is against this background that Clausewitz's notion of the most beautiful war should be understood and interpreted. It is the morality and the moral value of the people who participate in a people's war that motivate them to defend their territory. Clausewitz believes a people's war can overcome any other art of war, because it is the closest to the most perfect form of warfare. ${ }^{98}$ 
In the Clausewitzian idiom, freedom is the next central theme to define the most beautiful of wars, as it focuses the motivation and moral fabric of those who fight for freedom and independence. For Schiller, "beauty is the only possible expression of freedom in appearance". ${ }^{99}$ This builds on Kant's aesthetic theory, which established a link between beauty and freedom. That link exists in the sense that the experience of beauty liberates the individual from desire, while beauty forms the morality in a framework in which freedom plays a central role. ${ }^{100}$

Within this equation, it is crucial, however, to understand that there are dangers in overvaluing rationality over morality and vice versa. Clausewitz argues that Prussia's elites masked their fears as rational decisions and, as a result, became paralysed and incapable of action. He points out that fear paralyses reason whereas courage embedded in morality energises it. In many societies, freedom is stifled and unable to break out of the corruption of the state (elites). A lack of education also asphyxiates the attainment of individual freedom. The answer to this impasse is to create a holistic, aesthetic state in which individuals are regarded as whole beings, both rational and sensible, because they operate from inclination rather than from duty. Only in the aesthetic state and within its beauty is it possible to bring together the universal and the individual, the will of the whole and the nature of the individual.

Using this Clausewitzian lens, it is possible to deduce that during the South African War, the Boer militia and diehards integrated morality and rationality. They believed on a moral and a rational level that their battle and continued resistance against the imperial powers were both justified and legitimate. Within this unique blend of morality and rationality, their strong, individual religious beliefs played an important role. The South African Republic under Paul Kruger's leadership closely resembled a theocratic state, with the church in a central and dominant position acting as a moral compass. In addition, the Boer leaders believed on rational grounds that they could counter the British war effort as they had done so emphatically during the Anglo-Transvaal War of 1880-1881, when they relatively easily caught the imperial forces on the back foot. The Boer leaders and militia were, as a result, in high spirits during the opening weeks of the war, which gave them the capacity to resist and even repel the British forces. They believed they were occupying the moral high ground, and rationally argued that prolonging the war would prompt the international community to intervene on their side in reaction to the 'immoral war' imposed on them by the British government. The rationale was that a protracted war would tire the British forces, leading to more favourable peace terms for the Boers. ${ }^{101}$

The perfect balance between rationality and morality, which underpinned the South African War for the first few months, was severely tarnished after Cronjé's surrender. The initial reinforcement of and confluence between rationality and morality that had motivated and reinvigorated the Boer militia to achieve spectacular successes were slowly drained as the war dragged on. The red-letter day when the momentum swung was 27 February 1900, when two major setbacks occurred. On this date, the British forces first managed to break through the Boers' defensive lines at Pietershoogte on the Natal line, and Cronjé on the western front capitulated despite commanding a 
force of 4000 men. That loss was destined to have the most devastating impact on Boer morale, subsequently undermining their rational belief in their own military prowess. The Boers argued that, if a Boer general with almost 4000 men surrendered, what positive outlook was there for the two republics? ${ }^{102}$ General Piet de Wet, who had witnessed the surrender, conceded that the defeat and loss of almost ten per cent of the absolute Boer force crushed morale. ${ }^{103}$

After this, the British forces' unimpeded progress became a stark reality, with overwhelming numbers supported by superior artillery moving into the south-west Free State. The demoralised and shrinking numbers of Boer militia were unable, but also unwilling, to unite to oppose this absolute onslaught. On a moral level, there was a definite notion amongst their ranks that to carry on with a seemingly fruitless war against an overwhelming enemy was pointless, because it seemed to have only one logical and rational outcome. ${ }^{104}$ The dispirited Boer militia began melting away in the face of the advancing British war machine, having been stripped of the very disposition, morality and rationality, which had energised their war effort. Increasing numbers began questioning the wisdom of continuing with the war.

On 11 January 1902, Commandant Vilonel wrote a letter to President Steyn in which he referred to the continuation of the war as needless and devastating to their own people. Vilonel warned that he and other officers would be compelled to take up arms against fellow Boers in a civil war, if the fighting continued. ${ }^{105}$ His viewpoint was rooted in a strong rational and moral position, because he argued that the outcome of prolonging the war while women and children suffered in concentration camps was, in fact, an immoral position to take. General Piet de Wet took a similar position, which created a rift between him and his brother Christiaan. ${ }^{106}$

The Boer leaders, notably Presidents Kruger and Steyn, did their utmost to reinstate a strong sense of morality in their forces, to ensure that they stayed on the battlefield. At every available opportunity, these leaders appealed to their men on moral and religious grounds to unite and resist the invaders. Kruger travelled to Bloemfontein on 5 March 1900 with just that aim, addressing a large assembly of men and women at the station. He urged them to fight in the name of their trusted God, reminding them that if they truly believed in God, they would be able to defeat the might of the British Empire. He referred to those who laid down their arms and returned to their farms as not being true believers. ${ }^{107}$ Kruger's speech was deeply grounded in religion. Rather than restoring the morale of the fighters, there was the growing realisation of a bitter reality: the Boer forces were slowly succumbing in the face of the pressure exerted by the British war machine.

In early 1900, the sad loss of the integrated rationality and morality that had underpinned and motivated the Boer effort up to that point was vividly and cruelly exposed on a road south-west of Bloemfontein. On 6 March, President Kruger took position next to the road after the British forces had broken through at Poplar Grove. He was hoping that by directly appealing and encouraging the retreating and demoralised Boer forces he would be able to stop them from fleeing and would convince them 
to offer resistance. Kruger encouraged the combatants to make a stand and defend Bloemfontein, the capital of the Free State. He encouraged them to fight for their independence and reminded them that they would be victorious if they stood together. However, a large section of the burghers merely shook their heads - to them, their farms were more valuable than any capital city. Kruger angrily raised his walking stick and desperately instructed the Pretoria police to shoot at the retreating burghers, but to no avail - a steady stream of former fighters drained away from the front. The undisputed fact was that, morally and rationally, their spirits were broken. ${ }^{108}$

The retreating Boer forces and the fall of Bloemfontein on 13 March 1900 served as confirmation that the attackers had the upper hand. The zenith was reached when the Transvaal government decided not to defend Pretoria. General Smuts, in response, asked if Pretoria was not worth fighting for, what was? What would be the point of continuing with the war? ${ }^{109}$ The Clausewitzian notion of the beauty of war as the prerogative of those who fight for their independence on their own soil, imbued with the integrated strength of morality and rationality, was now just a distant and sad memory. On moral and on rational grounds, the 'joiners' and, to a lesser extent, the 'hands-uppers', were no longer prepared to support the Boers' war efforts. They argued that the republics had already been annexed, and that peace would end the suffering of the women and children in the concentration camps. ${ }^{110}$

However, not all burghers who abandoned the battlefield did so on moral and rational grounds, nor did they all take a principled stand on the matter. One noteworthy group was disloyal to the Boer cause, led by JG Fraser of the Free State Republic Assembly and former presidential candidate and doctor, BO Kellner, the mayor of Bloemfontein, who sympathised with the British and handed over the keys to the city to Lord Roberts. A significant portion of burghers were merely disinterested in prolonging the war. In the opinion of the bittereinders, they were cowards who no longer wanted to make an effort to keep fighting, and saw their farms and possessions as more important. ${ }^{111}$

The Boer forces fragmented into three significant groups, the die-hards or bittereinders, the 'joiners', and the 'hands-uppers' (who resided either with their families in the concentration camps or on their farms). This fragmentation was significant, given the small number of combatants who initially took a stand. During the last six months of the war, 5464 'joiners' fought on the side of the British and were opposed by only 17000 bittereinders. If the number of Boer prisoners of war is taken in account, close to 20000 'hands-uppers' had opted to abandon the struggle and the quest for freedom. ${ }^{112}$

This split between the die-hards and the 'joiners' or 'hands-uppers' was, however, not exclusively rooted in the interrelationship between or combination of morality and rationality, but it does explain why the bittereinders persisted with the struggle: they believed in the justness of their cause. This split amongst the Boer ranks is comparable to a civil war, because it developed in a battle between bittereinders and a superior British force supported by erstwhile fellow burghers/combatants. 
On 24 October 1949, a Mrs AC Meyer wrote to Die Volksblad, recounting some of the incidents during the war when women on farms were molested by black soldiers while the local 'joiners' hid on the fringes of the unit, too ashamed about possibly being recognised. This sheds light on the treatment of the 'joiners' after the war, and the people's deep contempt for and resentment towards them. ${ }^{113}$

\section{Concluding remarks}

In this article, the argument was made that in true Clausewitzian fashion, the Boer militia were a people's army fighting for independence on home soil. In this idiom, in their struggle against a powerful foe, the burghers were imbued with vitality thanks to the powerful interrelationship and integration between rationality and morality. This strong dual motivating force propelled them into the battle and gave them an advantage against a professional British army, which was fighting on different terms.

As explained here, the Boer defeat at Paardenberg and the surrender by almost 4000 fighting men demoralised the Boer fighters, dramatically unravelled their moral fibre and made them question their sense of rationality. The trickle of dispirited and demoralised men who abandoned the war became a stream and later a flood. The rolling momentum of the British advances drained the available manpower of the Boer militia and diminished any hope of negotiating from a position of strength.

The fundamental question is whether the demoralising effect of the loss of integrated morality and rationality could have been prevented. It is doubtful that the Boer Republics would have been able to stand their ground in the long run, given the empire's limitless resources and manpower. However, the Boer leaders had neglected numerous opportunities to gain the initiative. In Natal, General Piet Joubert refused to allow fighters on horseback to strike at the British forces who were defeated and scrambled back to Ladysmith. He could have delivered a devastating blow in a manner which would have resembled the 1881 victory at Majuba, and that would have energised the burghers. In similar fashion, the Boer leaders were unable to translate defensive positions into an offensive advantage at Magersfontein, where they had put the British on the back foot by attacking their vulnerable opponents. ${ }^{114}$ The British forces were at the mercy of the advancing Boers, who could have captured and seized their artillery and provisions, which would have been a devastating logistical tactic and a blow to British morale.

Even the defeat at Paardenberg, where Cronjé was forced to capitulate, offered an opportunity to regain the initiative and secure the fortunes of the republics. In the aftermath at Paardenberg, Lord Roberts's army was strategically and logistically paralysed, his soldiers tired, lacking food, and supplies of ammunition and fodder for the horses were at a low. A strong counterattack had a 'turn-around' potential, which the Boer leaders were unable to exploit. ${ }^{115}$

However, the pinnacle of strategic blunders occurred on 5 March, when the two presidents, Kruger and Steyn, delivered their peace initiative to the British 
government. Their political, military and strategic naivety was exposed in their belief that the British government would settle for peace (after losing many men at the beginning of the war) precisely at the juncture where the British were gaining the upper hand. If the successes during Black Week had been followed up with one or two more victories, the presidents would have been in a position to negotiate for peace from a position of strength.

Efforts at international diplomacy, led by Dr WJ Leyds, who had been sanctioned to convince European nations to intervene on behalf of the Boers, were also undermined because at that stage, the republics' war efforts were faltering. In international relations, it is uncommon for an international power to intervene in a lost cause; hence, their reluctance to support the burghers. However, the most damaging impact on the Boers' morale and their rational disposition was that the peace initiative created the impression that the two presidents viewed the war as a lost cause, and that their men were incapable of winning. The peace initiative left a tangible impression that the two Boer governments assumed the war was unwinnable; therefore, they were no longer prepared to continue fighting. The poorly timed peace initiative did much to dent the burghers' willingness to continue fighting and contributed to the sense of hopelessness that took hold of fighters in the field. ${ }^{116}$ In the end, the combination of rationality and morality, which had energised the men early, on was the determining factor that deflated the war effort and divided the nation.

\section{Endnotes}

${ }^{58}$ M Howard. Clausewitz. Oxford: Oxford University Press, 1983, 47-58.

${ }^{59}$ Ibid.

${ }^{60} \mathrm{R}$ Aron. Peace and war: A theory of international relations. London: Weidenfeld \& Nicolson, 1962, 22.

${ }^{61}$ S Scheipers. "The most beautiful of wars: Carl von Clausewitz and small wars". Journal of Strategic Studies, Volume 2, Issue 1, 2016. 1-25.

${ }^{62}$ A Herberg-Rothe. 'Clausewitz's 'wonderous trinity' as general theory of war and violent conflict”. Theoria, No 114. December 2007. 48.

${ }^{63}$ Ibid.

${ }^{64}$ A Heywood. Politics. London: McMillan Press, 2012, 134.

${ }^{65}$ C Daase. "Clausewitz and small wars". Paper presented at the conference

'Clausewitz in the $21^{\text {st }}$ Century' at Oxford University, 21-23. An edited version can be found in Clausewitz in the Twenty-First Century edited by Hew Strachan and Andreas Herberg-Rothe (Oxford University Press) September 2007.

\footnotetext{
${ }^{66}$ Ibid.

${ }^{67}$ Ibid.

${ }^{68}$ Howard op. cit., pp. 47-58.

${ }^{69}$ Scheipers op. cit., pp. 1-25.
} 
${ }^{70}$ Renier collection accession no. 8669, National Archive Bloemfontein, VAB/A 119.

${ }^{71}$ P Warwick. Black people and the South African War. Johannesburg: Ravan Press, 1983, 269.

${ }^{72}$ Howard op. cit., pp. 47-58.

${ }^{73}$ Ibid.

${ }^{74}$ L Scholtz. "Clausewitz, Moa Zedong en die Anglo Boereoorlog”. Journal of Contemporary History, Volume 25, No 2. December 2000. 14.

${ }^{75}$ Howard op. cit., pp. 47-58.

${ }^{76}$ A Gat. War in human civilisation. Oxford: Oxford University Press, 2005, 318.

${ }^{77}$ Daase op. cit., pp. 1-9.

${ }^{78}$ Scheipers op. cit., pp. 1-25.

${ }^{79}$ Ibid

${ }^{80}$ T Cameron (ed). New history of South Africa. Cape Town: Human \& Rousseau, 1977, 183-219.

${ }^{81}$ AN Porter. "British imperial policy and South Africa 1895-9". In P Warwick (general ed), The South African War 1899-1902. London: Longman, 1980, pp 239-258.

${ }^{82}$ Ibid.

${ }^{83}$ SB Spies \& G Nattrass. Jan Smuts: Memoirs of the Boer War. Johannesburg: Jonathan Ball, 1994, 53.

${ }^{84}$ Ibid.

${ }^{85}$ Howard op. cit., pp. 47-58.

${ }^{86} \mathrm{H}$ Bailes. "Military aspects of the war". In P Warwick (general ed), The South African War 1899-1902. London: Longman, 1980, pp 65-103.

${ }^{87}$ Ibid.

${ }^{88} \mathrm{JHH}$ Breytenbach. Die geskiedenis van die Tweede Vryheidsoorlog in Suid-Afrika, 1899-1902. Pretoria: Government Printer, 1978, 156; L Amery. The Times history of the Boer War, 1899-1902. London: Sampson Low, Marston \& Company, 1906.

${ }^{89}$ Bailes op. cit.

${ }^{90}$ Scholtz op. cit., p. 14.

${ }^{91}$ Breytenbach op. cit., p. 23.

${ }^{92}$ Ibid.

${ }^{93}$ Ibid.

${ }^{94}$ Ibid.

95 Ibid.

${ }^{96}$ Ibid.

${ }^{97}$ Ibid. 
${ }^{98}$ Scheipers op. cit.

${ }^{99}$ Ibid.

${ }^{100}$ Ibid.

${ }^{101}$ Breyenbach op. cit., p. 23.

${ }^{102}$ A Grundlingh. Hendsoppers en joiners: Die verskynsel en rasionaal van verraad. Pretoria: Protea, 2010, 257.

${ }^{103}$ CR de Wet. De Strijd tussen Boer en Brit: De Herinnering van den Boere-Generaal. Pretoria: Pretoria Boekhandel, 1902.

${ }^{104}$ P Steyn. "Verraaier of het hy vooruitgesien?" Volksblad, 13.4. 2013.

${ }^{105}$ Grundlingh op. cit., p. 257.

${ }^{106}$ De Wet op. cit.

${ }^{107}$ Breytenbach op. cit., p. 156.

${ }^{108}$ Ibid.

${ }^{109}$ Spies \& Nattrass op. cit.

${ }^{110}$ Grundlingh op. cit., p. 23.

${ }^{111}$ Ibid.

${ }^{112}$ Ibid.

${ }^{113}$ Renier collection op. cit.

${ }^{114}$ Breytenbach op. cit., p. 113.

115 Ibid.

${ }^{116}$ Breytenbach op. cit., p. 65. [Ibid. refers to the source directly above. So, if note 53 is Breytenbach, then this one should also be Ibid. Please check throughout that you use Ibid. correctly.] 